\title{
KAJIAN ETNOLINGUISTIK LEKSIKON BAHASA REMAJA MILENIAL DI SOSIAL MEDIA
}

\author{
Lailatul Fitriah ${ }^{1}$, Ayu Indah $\mathbf{P}^{2}$, Karimah ${ }^{3}$, Daroe Iswatiningsih ${ }^{4}$ \\ 1,2,3,4 Prodi Magister Pendidikan Bahasa Indonesia \\ Universitas Muhammadiyah Malang \\ Jalan Raya Tlogomas No. 246 Tlogomas, Babatan, Tegalgondo, Kec. Lowokwaru, Kota Malang \\ Surel: ${ }^{1}$ zahratullaila@webmail.umm.ac.id, ${ }^{2}$ aindah1997@ gmail.com, \\ 33arimah9296@webmail.umm.ac.id, ${ }^{4}$ daroe@umm.ac.id
}

\begin{abstract}
Abstrak
Bahasa mempunyai peran penting dalam proses perkembangan kehidupan remaja, salah satunya sebagai bentuk ekspresi remaja kaum milenial. Bahasa digunakan sebagai alat komunikasi dan interaksi, didalamnya terdapat simbol-simbol bunyi yang digunakan dalam suatu layar budaya khusus. Etnolinguistik mengkaji hubungan antara bahasa dan budaya serta pengaplikasiannya dalam kondisi budaya sosial tertentu. Hal tersebut dapat ditinjau pada penggunaan bahasa remaja milenial di sosial media yang dipengaruhi oleh perkembangan budaya masyarakat penuturnya. Tujuan penelitian ini untuk mengklasifikasikan leksem berdasarkan bahasanya dan bentuk leksem bahasa remaja milenial di sosial media. Penelitian ini menggunakan metode deskriptif kualitatif, data dikumpulkan dengan teknik pencatatan atau dokumentasi dan kajian kepustakaan.Wujud data penelitian berupa leksem pada bahasa remaja milenial yang digunakan dalam komunikasi di sosial media instagram, twitter, dan tiktok. Hasil penelitian menunjukkan leksem bahasa remaja milenial di sosial media, 1) 33 leksem berasal dari bahasa Indonesia. 2) 8 leksem diadobsi dari bahasa daerah. 3) 16 leksem diadobsi dari bahasa Inggris. 4) 11 leksem diadibsi dari bahasa Korea. 5) bentuk bahasa remaja milenial di sosial media terdiri dari 21 bentuk singkatan, 20 bentuk akronim, dan 4 bentuk pemendekan kata.
\end{abstract}

Kata Kunci: leksem , remaja milenial, sosial media, etnolinguistik

\section{A. PENDAHULUAN}

Perkembangan budaya akan mempengaruhi perkembangan bahasa, karena bahasa dan budaya merupakan satu kesatuan yang tidak terpisahkan. Bahasa dapat dikatakan sebagai salah satu wujud dan alat untuk mendokumentasikan budaya. Kenyataan yang terjadi, cara berbahasa seseorang mempengaruhi dan dipengaruhi oleh kebudayaannya (Sutardi, 2007:77). Hubungan antara bahasa dan budaya dikaji dalam bidang etnolinguistik, namun menurut Mulyani (2020:12) etnolinguistik tidak hanya menelaan bahasa dari segi strukturnya, tetapi lebih pada kegunaan dan pengaplikasiannya dalam kondisi sosial budaya sebagai alat komunikasi.

Penggunaan bahasa sebagai alat komunikasi saat ini sangat diperlukan sebab bahasa merupakan aspek yang tidak terlepas dari penggunaan dalam kehidupan masyarakat seharihari. Bahasa merupakan alat komunikasi yang digunakan antar anggota masyarakat dalam kehidupan sehari- hari, oleh sebab itu penggunaan bahasa sebagai alat komunikasi meliputi 
keseluruhan aspek kebudayaan dalam kehidupan masyarakat, di antaranya adat istiadat, alat penunjang bagi kehidupan sehari- hari seperti dalam bidang pertanian dan transportasi. Komunikasi sendiri merupakan suatu proses informasi antar individual yang ditukarkan melalui sistem simbol, tanda, atau tingkah laku yang umum (Alwasillah, 1986:9). Sehingga dengan kata lain, komunikasi sangatlah penting untuk mengutarakan suatu kehendak yang diinginkan ataupun disampaikan tentunya menggunakan bahasa sebagai perantara.

Bahasa remaja milenial saat ini sangat beragam, baik dari pengambilan bahasa daerah ataupun bahasa asing. Penggunaan bahasa remaja milenial pada saat ini sering digunakan secara langsung dalam penggunaan sosial media. Konsep bahasa adalah alat untuk melahirkan ungkapan-ungkapan batin yang ingin disampaikan seseorang penutur kepada orang lain (Chaer, 2009: 33). Ada beberapa fungsi bahasa menurut Chaer, yaitu (1) fungsi informasi, (2) fungsi eksplorasi, (3) fungsi persuasi, dan (4) fungsi Entertainment. Banyaknya penggunaan bahasa remaja saat ini membuat jumlah bahasa-bahasa yang ada saat ini semakin beragam. Oleh sebab itu, penelitian ini dilakukan untuk mengetahui bahasa remaja milenial yang beragam dan juga mengetahui asal bahasa yang digunakan. Fungsifungsi menurut Chaer ini sangat sesuai dengan penerapan bahasa pada saat ini, apalagi penggunaan bahasa remaja milenial yang semakin beragam.

Turner dan Helms mengemukakan, remaja adalah individu yang berkembang dari masa kanak-kanak menuju masa dewasa, masa remaja berkisar antara umur 12 atau 13 tahun sampai umur belasan atau awal umur dua puluhan (Putro, 2017: 25). Kalangan remaja, menggunakan bahasa milenial selain untuk berkomunikasi juga untuk menunjukkan eksistensi diri. Bahasa milenial berbeda dengan bahasa masyarakat lainnya, berbedaan tersebut dilihat dari tataran kebahasaan, fonologi, morfologi dan sintaksisnya (Wijaya, 2010 :6). Selain itu bahasa milenial memiliki beberapa ciri khusus diantaranya, ringkas, cakap, dan kreatif (Ertika dan Dian, 2019: 86). Pilihan kata yang digunakan umumnya singkat dan kata yang agak panjang diperpendek dengan proses morfologi dan menggantinya dengan kata lain yang lebih singkat.

Penelitian mengenai bahasa remaja milenial pernah dilakukan oleh Ertika dan Dian (2019) dengan judul Ragam Bahasa Gaul Kalangan Remaja di Kota Bengkulu. Hasil penelitian menyebutkan ragam bahasa gaul remaja kota Bengkulu terdiri dari nasalisasi, ng, -a, -da, - na, -se, -es, -ra, -s, dan -ong, sisipan -ok, walikan, pengulangan, Bahasa Inggris, dan berpola acak. Penelitian selanjutnya oleh Swandy (2017) dengan judul Bahasa 
Remaja Gaul Dalam Sosial Media Facebook. Hasil penelitinya bahasa gaul jenis slank yang digunakan berinteraksi di media sosial facebook terdiri dari jargon, prokem dan colloqial. Penelitian berikutnya oleh Arisanti (2018) dengan judul Penggunaan Akronim dan singkatan Dalam Media Sosial Facebook di Kalangan Remaja SMK Plus Multazam. Hasil penelitian menyebutkan karakteristik akronim dan singkatan dalam facebook di kalangan temaja SMK Plus Multazam berasal dari kosa kata bahasa Inggris dan kosa kata bahasa Indonesia. Bahasanyapun tidak baku dan prokem yang digunakan lebih banyak dalam bentuk akronim dari pada bentuk singkatan. Penelitian selanjutnya oleh Goziyah dan Maulana (2019) dengan judul Bahasa Gaul Generasi Milenial di sosial Media. Hasil penelitian menyebutkan bahasa gaul remaja milenial di sosial media berupa singkatan dan kata-kata pendek.

Penelitian mengenai Kajian etnolingusitik sebelumnya juga pernah dilakukan oleh Hilman (2020) dengan judul Wujud Kebudayaan Dalam Tradisi Suna Ro Ndoso: Kajian Etnolinguistik. Hasil penelitian menunjukkan bahwa wujud dari ide, gagasan, nilai, norma, dan peraturan terlihat sebagai wujud ide/gagasan tentang ketuhanan, keselamatan, dan keberanian. Wujud aktivitas serta tindakan berpola ditemukan kurang lebih sekitar 13 kumpulan aktivitas serta tindakan berpola dari manusia dalam masyarakat pada prosesi suna ro ndoso. Wujud sebagai benda-benda hasil karya manusia yang terdapat dalam prosesi suna ro ndoso masyarakat Dompu, ditemukan kurang lebih sekitar 50. Namun peneliti belum menemukan kajian etnolinguistik pada bahasa remaja milenial sehingga kemungkinan penellitian ini adalah yang pertama kali.

Perbedaan penelitian ini dengan penelitian sebelumnya mengenai bahasa remaja milenial yaitu penelitian ini mengkaji bahasa yang digunakan di media sosial dari segi bentuknya serta pengklasifikasian leksikon berdasarkan asal bahasanya. fokus penelitian ini lebih mengarah kepada ragam bahasa remaja milenial yang digunakan berkomunikasi tulis pada sosial media saat ini. Tujuan penelitian ini untuk mengetahui bentuk bahasa milenial serta mengklasifikasikan leksikon bahasa remaja milenail berdasarkan asal bahasanya. Sehingga bermanfaat sebagai bahan referensi bagi penelitian yang membahas mengenai perkembangan bahasa remaja milenial saat ini. 


\section{B. KAJIAN TEORI}

\section{a. Leksikon}

Dalam linguistik, leksikon merupakan koleksi leksem pada suatu bahasa. Istilah ini berasal dari bahasa Yunani 'lexikón' yang bermakna 'perihal kata'. Kajian terhadap leksikon mencakup apa yang dimaksud dengan kata, strukturisasi kosakata, penggunaan dan penyimpanan kata, pembelajaran kata, sejarah dan evolusi kata (etimologi), hubungan antar kata, serta proses pembentukan kata pada suatu bahasa. Adapun menurut KBBI (2012: 345), leksikon diartikan sebagai kosakata, kamus sederhana, daftar istilah dalam suatu bidang disusun menurut abjad dan dilengkapi dengan keterangannya, komponen bahasa yang memuat semua informasi tentang makna dan pemakaian kata dalam bahasa atau kekayaan kata yang dimiliki suatu bahasa.

\section{b. Etnolinguistik}

Etnolinguistik merupakan 1) cabang linguistik yang menyelidiki hubungan antara bahasa dan masyarakat pedesaan atau masyarakat yang belum memiliki tulisan, bidang ini juga disebut dengan linguistik antropologi 2) cabang linguistik antropologi yang mengkaji hubungan bahasa dan sikap bahasawan terhadap bahasa (Kridalaksana, 2001: 52). Hal yang sama juga diungkapkan oleh Mbete (2007: 10) bahwa etnolinguistik disebut juga sebagai linguistik antropologi atau linguistik kultural (cultural linguistics) yang membedah pilihmemilih penggunaan bahasa, cara dan pola pikir dalam kaitannya dengan pola penggunaan bahasa, bahasa ritual, dan kreasi wacana iklan yang berbasiskan bahasa lokal. Sementara itu, Abdullah (2013:10) mengatakan bahwa, etnolinguistik adalah jenis linguistik yang menaruh perhatian terhadap dimensi bahasa (kosakata, frasa, klausa, wacana, dan unit-unit lingual lainnya) dalam dimensi sosial dan budaya (seperti upacara ritual, peristiwa budaya, folklor dan lainnya) yang lebih luas untuk memajukan dan mempertahankan praktik praktik budaya dan struktur sosial masyarakat. Duranti (1997:6) mengemukakan bahwa etnolinguistik adalah kajian bahasa dan budaya yang merupakan subbidang utama dari antropologi. Antropologi Linguistik telah mengalami transformasi yang cukup besar dalam beberapa dekade. Karena adanya perkembangan zaman dan perbedaan generasi banyak penelitian menemukan beberapa kajian yang dapat diterapkan melalui linguistik terapan, sosiologi, cerita rakyat, studi kinerja, filsafat, etnomusikologi, dan komunikasi. 
Pendapat lain mengatakan bahwa etnolinguistik adalah ilmu yang meneliti seluk beluk hubungan aneka pemakaian bahasa dengan pola kebudayaan. Dalam pandangan etnolinguistik, terdapat keterkaitan antara bahasa dengan pandangan dunia penuturnya. Merujuk pada pengertian etnolinguistik yang telah dikemukakan di atas dapat disimpulkan bahwa etnolinguistik adalah ilmu yang mempelajari tentang seluk-beluk hubungan pemakaian bahasa melalui masyarakat dan budaya. Dengan demikian, dapat dikatakan bahwa etnolinguistik merupakan ilmu yang mengkaji tentang bahasa dalam penggunaannya pada masyarakat penuturnya. Penggunaan bahasa dalam masyarakat dapat dilihat dari dimensi sosial dan budaya, seperti upacara ritual, peristiwa budaya, folklor dan lainnya. Objek kajian penelitiannya berupa daftar kata-kata, pelukisan dari ciri-ciri, dan pelukisan dari tata bahasa dan bahasa-bahasa lokal.

\section{c. Akronimisasi}

Akronim adalah singkatan yang berupa gabungan huruf awal, gabungan suku kata, ataupun gabungan huruf kata dari deret kata yang diperlukan sebagai kata (Husain, 1994:20). Menurut Sudaryanto (1993) akronim adalah satuan kebahasaan hasil dari penyingkatan dengan cara tertentu, yaitu dengan mengambil bagian-bagian kata yang bersangkutan yang disebut silabe atau yang mungkin menjadi silabe kata baru hasil penyingkatan satuan yang disingkat itu. Bentuk akronim dapat berupa gabungan huruf awal, gabungan suku kata, ataupun gabungan kombinasi huruf dan suku kata dari deret kata yang dilafalkan sebagai kata yang wajar. Contoh dalam bahasa Indonesia, pinca (pimpinan cabang), kanwil (kantor wilayah), pemda (pemerintah daerah), dan sebagainya. Adanya kenyataan akronim berpotensi menimbulkan pasangan homonim mendorong humoris menciptakan akronimakronim baru yang terasa aneh bagi akronim yang sudah dikenal secara luas. Sebagai contoh adalah sekwilda ( sekretaris wilayah daerah) dijadikan humor seks sehingga menjadi sekitar wilayah dada.

Semakin bervariasinya bentuk singkatan, akronim, atau pemendekan menjadi salah satu bukti berkembangnya bahasa. Pemendekan yaitu proses, cara, perbuatan memendekkan (Alwi (ed.), 2007: 849). Pemendekan merupakan proses penanggalan bagian-bagian leksem sehingga menjadi sebuah bentuk singkat, tetapi maknanya tetap sama dengan makna bentuk utuhnya (Chaer, 2003: 191). Pemendekan dalam bahasa Indonesia meliputi pemenggalan, kontraksi, akronim, dan singkatan. Pemendekan tersebut sering dijumpai dalam koran, iklan 
atau surat kabar, tabloid, majalah, televisi, radio, iklan, dan lain-lain. Kontraksi merupakan salah satu bentuk pemendekan

\section{d. Singkatan}

Singkatan adalah salah satu hasil proses pemendekan yang berupa huruf atau gabungan huruf, baik yang dieja huruf demi huruf maupun yang tidak dieja huruf demi huruf (Kridalaksana, 2007:162). Menurut Kamus Besar Bahasa Indonesia (KBBI, 2012:1313) singkatan adalah hasil menyingkat (memendekkan) yang berupa huruf atau gabungan huruf (misalnya DPR, KKN, yth). Dengan demikian, semua kependekan atau frase itu dapat digolongkan kedalam singkatan. Singkatan juga berarti hasil menyingkat (memendekkan). Menurut pusat dan pengembangan bahasa, singkatan adalah bentuk yang dipendekkan yang terdiri atas satu huruf atau lebih. Jadi dapat disimpulkan singkatan adalah bentuk huruf yang dipendekkan atau disingkat.

\section{METODE PENELITIAN}

Penelitian ini menggunakan metode deskriptif kualitatif. Menurut Bogdan san Taylor (dalam Mamik, 2015: 4), penelitian kualitatif menghasilkan data-data deskriptif berupa kata tertulis maupun verba dari manusia atau tingkah laku yang diamati. Metode deskriptif menjabarkan fenomena apa adanya sesuai dengan fakta tanpa ada kecurangan dan buatan (Hamdi dan Bahruddin, 2014: 6). Wujud data pada penelitian ini berupa bentuk bahasa milenial yang sering digunakan dalam komunikasi tertulis di sosial media instagram, twitter dan tiktok. Adapun sumber data penelitian ini adalah kolom komentar media sosial Instagram, twitter dan tiktok. Data dikumpulkan dengan cara teknik catat, kajian kepustakaan serta dokumentasi yang dilakukan pada bulan Desember-2020 hingga Januari 2021. Data dianalisis dengan mengklasifikasi bentuk bahasa remaja milenial dan kategorisasi bahasa remaja milenial berdasarkan asal bahasanya, dilanjutkan dengan mendeskripsikan maknanya.

\section{E. HASIL DAN PEMBAHASAN}

Bahasa remaja milenial di sosial media sangat beragam, hal tersebut dipengaruhi oleh budaya sekitarnya. Bahasa remaja milenial dapat digolongkan dari segi bentuknya serta digolongkan berdasarkan leksikon asal bahasanya yang terdiri dari leksikon asli dari bahasa 
Indonesia, leksikon yang diadopsi dari bahasa daerah, leksikon yang diadopsi dari Inggris dan leksikon yang di adopsi dari bahasa Korea.

\section{a. Bentuk Bahasa Remaja Milenial di Media Sosial}

Bentuk bahasa remaja milenial umumnya berupa singkatan, akronim, dan pemendekan kata. Pembentukan singkatan, akronim dan pemendekan kata dalam penggunaan bahasa biasa terjadi, hal tersebut dikarenakan sebagai upaya untuk mempermudah pengucapan serta mengingat maknanya. Tabel berikut merupakan bentuk bahasa remaja milenial yang digunakan dalam komunikasi tulis di sosial media.

Tabel 1 Bentuk bahasa remaja milenial

\begin{tabular}{|c|c|c|c|c|}
\hline No & Bentuk & Proses & Hasil Bentukan & Jumlah \\
\hline 1 & Singkatan & $\begin{array}{l}\text { Mengambil huruf } \\
\text { atau fonem pertama } \\
\text { dari kata yang } \\
\text { membentuk konsep. }\end{array}$ & $\begin{array}{l}\text { GPL, EGP, CLBK, PHP, } \\
\text { BT, B, CPCP, TPTP, } \\
\text { BTW, COD, OTW, DP, } \\
\text { DM, BF, GWS, COD, } \\
\text { OMG, FYP, CO, LOL, GJ }\end{array}$ & 21 singkatan \\
\hline 2 & Akronim & \begin{tabular}{|lr} 
Mengambil r & suku \\
pertama dari & semua \\
kata & yang \\
membentuk & konsep
\end{tabular} & $\begin{array}{l}\text { Omdo, kepo, gatot, pansos, } \\
\text { cinlok, mantul, baper, } \\
\text { gabut, gercep, alay, curcol, } \\
\text { mager, bucin, japri, bapuk, } \\
\text { macan, heri, salfok, bigos, } \\
\text { mabar, }\end{array}$ & 20 akronim \\
\hline 3 & $\begin{array}{l}\text { Pemendekan } \\
\text { kata }\end{array}$ & $\begin{array}{l}\text { Mengambil dari } \\
\text { suku kata yang } \\
\text { dominan dari } \\
\text { ketiap } \\
\text { kata }\end{array}$ & Bro, nampol, ababil, agan & $\begin{array}{l}4 \\
\text { pemendekan } \\
\text { kata }\end{array}$ \\
\hline
\end{tabular}

Tabel 1, terdapat beberapa bentuk bahasa milenial yang digunakan di media sosial, diantaranya berupa singkatan, akronim, dan pemendekan kata. Baris pertama, berupa singkatan diambil dengan cara mengambil huruf-huruf atau fonem-fonem yang berada di 
awal kata. Bentuk singkatan misalkan GPL kepanjangan dari gak pakai lama, kata gak pemendekan dari kata tidak. Fonem $/ g /, / p /, / l /$ pada awal setiap kata diambil sebagai singkatan, oleh karena itu penulisannya harus menggunakan huruf kapital. Hal serupa juga terjadi pada leksem yang diadopsi dari bahasa Inggris seperti COD yang merupakan kepanjangan dari cash on delivery mempunyai arti dalam bahasa bayar di tempat.

Bentuk akronim terdapat pada tabel 1 baris ke 2. Proses akronimisasi dengan mengambil suku pertama dari semua kata yang membentuk konsep, misalkan bucin pemendekan dari kata budak cinta. Kata tersebut jika dipisah berdasarkan suku katanya menjadi /bu-dak/,/cinta/ kata pertama memiliki suku awal /bu/ dan kata kedua memiliki suku awal/cin/. Bentuk pemendekan kata terdapat pada tabel 1 baris ke 3, dengan mengambil suku kata yang dominan dari setiap kata misalkan agan yang merupakan pemendekan dari kata juragan. Kata tersebut jika dipisah berdasarkan suku katanya menjadi /ju-ra-gan/ yang memiliki suku kata dominan /gan/ sehingga menjadi leksem /agan/.

\section{b. Kategori Leksikon Bahasa Remaja Milenial di sosial Media}

Budaya masyarakat juga mempengaruhi leksikon bahasa remaja milenial yang digunakan dalam berkomunikasi di sosial media. Sehingga jika dikategorikan berdasarkan asal bahasanya leksikon tersebut terdiri dari leksikon yang berasal dari bahasa Indonesia, leksikon yang diadopsi dari bahasa Jawa, leksikon yang di adopsi dari bahasa Inggris, dan leksikon yang berasal dari bahasa Korea. Berikut tabel kategorisasi leksikon tersebut.

Tabel 2 Tabel kategorisasi leksikon bahasa remaja milenial di sosial media

\begin{tabular}{l|l|l}
\hline No. & \multicolumn{1}{|c}{ Kategori leksikon } & Jumlah \\
\hline $\mathbf{1}$ & Kategori leksikon yang berasal dari bahasa Indonesia & 33 leksem \\
\hline $\mathbf{2}$ & Kategori leksikon yang diadopsi dari bahasa daerah & 8 leksem \\
\hline $\mathbf{3}$ & Kategori leksikon yang diadopsi dari bahasa Inggris & 16 leksem \\
\hline $\mathbf{4}$ & Kategori leksikon yang diadopsi dari bahasa Korea & 11 leksem \\
\hline
\end{tabular}


Leksikon yang digunakan di media sosial oleh remaja milenial untuk berkomunikasi secara tertulis ditunjukkan pada tabel 2 yaitu, leksikon yang berasal dari bahasa Indonesia lebih banyak menempati aturan yang pertama yaitu sejumlah 33 leksem. Kategori leksikon yang diadopsi dari bahasa Inggris sebanyak 16 leksem. Kategori leksikon yang diadopsi dari bahasa Korea sebanyak 11 leksem. Sedangkan leksikon yang diadopsi dari bahasa daerah paling sedikit dari pada yang lainnya yaitu 8 leksem.

\section{Leksikon Remaja Milenial dari Bahasa Indonesia}

Bahasa Indonesia sebagai bahasa Nasional juga di gunakan oleh remaja milenial untuk berkomunikasi secara tertulis di media sosial. Hal tersebut dapat dicermati dari leksem yang digunakan para remaja tersebut, baik dari makna maupun pengaplikasiannya dalam berkomunikasi tertulis. Bentukan leksem dari Bahasa Indonesia, umum digunakan hampir di semua sosial media, karena leksem ini mudah dipahami. Leksem yang digunakan para remaja tersebut terdapat dalam tabel berikut ini.

Tabel 3 Kategori leksikon yang berasal dari bahasa Indonesia

\begin{tabular}{llll}
\hline No & Bentukan & Asal Kata/leksem & Makna leksem \\
\hline $\mathbf{1}$ & Pansos & Panjat sosial & Bentuk perilaku dari seseorang yang \\
& & ingin menunjukkan dan meningkatkan \\
& & status sosial mereka \\
\hline $\mathbf{2}$ & Cinlok & Cinta lokasi & Perasaan cinta yang timbul karena \\
& & intensitas waktu yang telah dihabiskan \\
& & bersama di suatu lokasi tertentu \\
\hline $\mathbf{3}$ & Mantul & Mantul betul & Kata yang sering digunakan untuk \\
& & mengapresiasi; seperti pujian \\
\hline $\mathbf{4}$ & Gabut & Gaji buta & Orang memiliki penghasilan namun \\
& & tidak melakukan kegiatan; perasaan \\
& & tidak jelas harus berbuat apa \\
\hline $\mathbf{5}$ & Gercep & Gerak cepat & Anjuran kepada seseorang untuk bisa \\
& & bergerak lebih cepat saat melakukan \\
& & Anak layangan & Norak, berlebihan dan hiperbola \\
\hline $\mathbf{6}$ & Alay & &
\end{tabular}




\begin{tabular}{|c|c|c|c|}
\hline 7 & $G j$ & Gak jelas & $\begin{array}{l}\text { Singkatan yang digunakan saat } \\
\text { seseorang tidak paham atau tidak bisa } \\
\text { menangkap maksud orang lain }\end{array}$ \\
\hline 8 & Curcol & Curhat colongan & $\begin{array}{l}\text { Ungkapan hati yang tidak sengaja } \\
\text { untuk diceritakan atau dikeluarkan dan } \\
\text { pendengar pun tidak mengetahui } \\
\text { sebelumnya yang dikatakan pembicara } \\
\text { adalah curahan hati }\end{array}$ \\
\hline 9 & Mager & Malas gerak & $\begin{array}{l}\text { Ditujukan bagi seseorang yang tidak } \\
\text { banyak beraktivitas }\end{array}$ \\
\hline 10 & Palbis & Paling Bisa & $\begin{array}{l}\text { Seseorang yang mudah mengelak atas } \\
\text { apa yang seharusnya bertanggung } \\
\text { jawab }\end{array}$ \\
\hline 11 & Bucin & Budak cinta & $\begin{array}{l}\text { Julukan bagi seseorang yang turut } \\
\text { dengan pacar akibat terlalu cinta }\end{array}$ \\
\hline 12 & Japri & $\begin{array}{l}\text { Jalur pribadi atau } \\
\text { jaringan pribadi }\end{array}$ & $\begin{array}{l}\text { Istilah untuk ceting berdua saja, tidak } \\
\text { dengan anggota lainnya. }\end{array}$ \\
\hline 13 & Bapuk & barang lapuk & 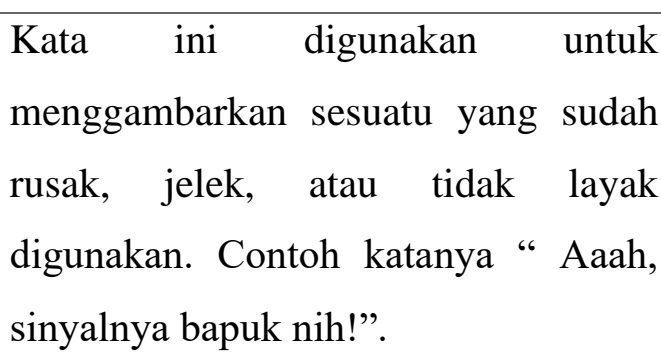 \\
\hline 14 & Macan & Mama cantik & $\begin{array}{l}\text { Sebutan untuk ibu muda yang masih } \\
\text { tetapmuda meskipun sudah memiliki } \\
\text { anak. }\end{array}$ \\
\hline 15 & Heri & Heboh sendiri & $\begin{array}{l}\text { Kata yang digunakan untuk } \\
\text { mengungkapkan keadaan seseorang } \\
\text { yang terlalu heboh dalam menanggapi } \\
\text { sesuatu }\end{array}$ \\
\hline 16 & Salfok & Salah fokus & $\begin{array}{l}\text { Pemendekan kata yang digunakan } \\
\text { untuk mengungkapkan keadaan }\end{array}$ \\
\hline
\end{tabular}




\begin{tabular}{|c|c|c|c|}
\hline & & & seseorang $\quad$ yang \\
\hline & & & $\begin{array}{l}\text { teralihkan oleh sesuatu yang } \\
\text { seharusnya tidak ia perhatikan }\end{array}$ \\
\hline 17 & Ababil & ABG labil & $\begin{array}{l}\text { Sebutan untuk anak muda yang } \\
\text { masih temperamental dan kekanak- } \\
\text { kanakan }\end{array}$ \\
\hline 18 & Bigos & Biang gosip & $\begin{array}{l}\text { Sebutan pada orang yang mengawali } \\
\text { menyebarkan gosip. }\end{array}$ \\
\hline 19 & Mabar & Main bareng & $\begin{array}{l}\text { (Games); biasa di gunakan anak } \\
\text { komunitas Games tertentu yang akan } \\
\text { mengajak temannya main. }\end{array}$ \\
\hline 20 & Jones & Jomblo ngenes & $\begin{array}{l}\text { Sebutan untuk seseorang yang tidak } \\
\text { punya pacar sehingga sering dihina } \\
\text { teman-temannya }\end{array}$ \\
\hline 21 & Baper & bawa perasaan; & Menyatakan terbawa perasaan \\
\hline 22 & Murce & murah cekali & $\begin{array}{l}\text { Menyatakan kebahagiaan karena } \\
\text { mendapatkan harga yang murah ketika } \\
\text { berbelanja }\end{array}$ \\
\hline 23 & Nampol & enak pol & $\begin{array}{l}\text { Biasanya dilakukan untuk memuji } \\
\text { kelezatan suatu masakan. }\end{array}$ \\
\hline 24 & Agan & Jugaran & $\begin{array}{l}\text { Biasanya digunakan sebagai sapaan } \\
\text { dalam dunia online shop }\end{array}$ \\
\hline 25 & $G P L$ & Gak pake lama & $\begin{array}{l}\text { Biasanya diungkapkan oleh seseorang } \\
\text { yang tidak ingin menunggu terlalu } \\
\text { lama }\end{array}$ \\
\hline 26 & $E G P]$ & Emang gue pikirin & $\begin{array}{l}\text { Ungkapan kejengkelan dan seolah- } \\
\text { oleh tidak peduli dengan suatu hal }\end{array}$ \\
\hline 27 & $C L B K$ & $\begin{array}{l}\text { Cinta lama bersemi } \\
\text { kembali }\end{array}$ & $\begin{array}{l}\text { Istilah ini digunakan pada seseorang } \\
\text { yang kembali kepada mantan } \\
\text { kekasihnya setelah lama sudah putuh } \\
\text { hubungan }\end{array}$ \\
\hline
\end{tabular}




\begin{tabular}{|c|c|c|c|}
\hline 28 & PHP & Pemberi harapan palsu & $\begin{array}{l}\text { Sebutan bagi seseorang yang tidak } \\
\text { mampu berkata secara langsung tetapi } \\
\text { sikapnya mengisyaratkan sesuatu. }\end{array}$ \\
\hline 29 & $B$ 'aja' & 'biasa' saja & $\begin{array}{l}\text { Kata ini digunakan untuk menanggapi } \\
\text { kwalitas sesuatu misalkan barang }\end{array}$ \\
\hline 30 & Cpcp] & cari perhatian & $\begin{array}{l}\text { Tindakan seseorang yang dikarenakan } \\
\text { dia tidak mendapatkan perhatian yang } \\
\text { dibutuhkannya }\end{array}$ \\
\hline 31 & Tptp & tebar pesona & $\begin{array}{l}\text { seseorang yang suka memamerkan } \\
\text { kelebihannya didepan seseorang yang } \\
\text { dia suka }\end{array}$ \\
\hline
\end{tabular}

Tabel 3 menunjukkan banyaknya leksem bahasa gaul yang berasal dari Bahasa Indonesia yaitu 31 leksem. Berdasarkan bentuknya yaitu pansos, cinlok, mantul, baper, gabut, gercep, alay, geje, curcol, mager, palbis, bucin, japri, bapuk, macan, heri, salfok, ababil, bigos, mabar, jones, murce, nampol, agan, GPL , EGP, CLBK, PHP , B , CPCP , TPTP . Berikut ini Konteks beberapa bentuk bahasa milenial yang berasal dari Bahasa Indonesia.

1. @ bqtwyu: salfok kupingnya diska (tanda ekspresi), btw yeayy @ nicenxawaw: Diska kupingnya ke crop ya itu kak? (@sarahgibson/12 Januari 2021)

2.@ @arlitanova : sar lancar2 yaa @yvelhaf: mantul (@sarahgibson/12 Januari 2021)

3. @rachgoddard:Cantik bangeeeettt 20 @ danieltopanofficial :B aja...(@sarahgibson/12 Januari 2021

Kalimat tersebut diungkapkan penggemar artis Sarah Gibson dalam kolom komentar akun Instagramnya @sarahgibson. Kalimat 1 ditulis oleh pemilik Instagram @ bqtwtu, dia menggunakan akronim salfok yang berasal dari leksem salah fokus ketika perhatiannya jatuh pada telinga Diska, di foto yang di unggah telinga Diska hanya kelihatan pangkal daun telinganya sehingga kelihatan seperti benjolan kecil menempel di pipi. Namun berbeda dengan kalimat 2 yang di ungkapkan oleh pemilik akun Instagram @yvelhaf, dia 
menggunakan akronim mantul yang berasal dari leksem mantab betul untuk mengungkapkan kekagumannya pada pasangan Sarah Gibson dan Diska yang memiliki paras cantik dan tampan serta sangat serasi. Kalimat 3 komentar yang ditulis oleh pemilik akun @ rachgoddard , dia memuji kecantikan Sarah Gibson namun disanggah oleh pemilik akun @ danieltopanofficial menggunakan singkatan $B$ aja yang bermakna biasa saja.

\section{Leksikon yang Diadopsi dari Bahasa Daerah}

Kebudayaan juga berpengaruh terhadap perkembangan bahasa, hal tersebut dibuktikan dengan penggunaan bahasa milenial yang diadopsi dari bahasa daerah. Mayoritas leksem bahasa daerah diambil dari bahasa Jawa dan ada beberapa dari bahasa lain misalkan bahasa Madura. Leksem dari bahasa daerah umunya digunakan oleh komunitas remaja dari daerah tertentu, namun beberapa leksikon menjadi umum digunakan karena faktor kebiasaan dan sudah dipahami oleh semua orang misalkan leksem ambyar, tuman, dan konco. Berikut tabel leksem yang diadopsi dari bahasa daerah.

Tabel 4 Kategori leksikon yang diadopsi dari bahasa daerah

\begin{tabular}{l|l|l}
\hline No & Leksem & Makna \\
\hline $\mathbf{1 .}$ & Madt & Bermakna kawan \\
\hline $\mathbf{2 .}$ & Soro & Banget \\
\hline $\mathbf{3}$ & Ambyar & Hancur \\
\hline $\mathbf{4}$ & Edun & Edan atau gila \\
\hline $\mathbf{6}$ & Guman & $\begin{array}{l}\text { Maknanya kira-kira “kebiasaan banget deh!" KBBI: menjadi } \\
\text { biasa (suka, gemar dan sebagainya) }\end{array}$ \\
\hline $\mathbf{7}$ & Ker & Bentuk pemendekan dari Gagal total \\
\hline $\mathbf{8}$ & Semongko & $\begin{array}{l}\text { Sebalikan dari rek yang merupakan pemendekan dari kata } \\
\text { arek dari bahasa Jawa, dalam bahasa Indonesia berarti teman. }\end{array}$ \\
\hline
\end{tabular}




\begin{tabular}{l|l|l}
\hline 9 & konco & $\begin{array}{l}\text { Berasal dari bahasa Jawa, yang maknanya teman dalam } \\
\text { bahasa indonesia }\end{array}$ \\
\hline
\end{tabular}

Tabel 4 menunjukkan leksem bahasa milenial yang di adopsi dari bahasa daerah tidak terlalu banyak yaitu 8 leksem. Leksem tersebut diadopsi dari Bahasa Madura, seperti leksem madt, dan soro. Leksem yang diadopsi dari Bahasa Jawa, seperti leksem ambyar, edun, tuman, gatot, ker, semongko, konco. Berikut ini konteks beberapa leksem yang terdapat di media sosial.

4. @Dina Agustin: Jember lek gibah mantep soro @arisa_saraswati : Jember [1. (tiktok/8 Januari 2021)

5. SusantoAguzz@aguzbwanget: biyen odading saiki semongko,ket biyen ngomong bersanding, nganti saiki rong opo-opo...

(dulu odading sekarang semangka, dari dulu katanya bersanding, sampai sekarang belum apa-apa)

RiskaFadhilah@riskafadhilahh: hahahaha....semongko (tweeter/25 September 2020)

Kalimat 4 tulis oleh@Dina Agustin diakun tiktok komunitas remaja Jember. Penggunaan leksikon soro yang bermakna banget merupakan bahasa Madura khas Jember dan kemungkinan hanya diketahui maknanya oleh komunitas remaja Jember. Namun pada kalimat 5, penggunaan leksikon semongko dalam bahasa milenial berarti semangat yang ditulis oleh@ @riskafadhilahh yang ditujukan untuk memberi semangat kepada pemilik akun tweeter@aguzbwanget karena unggahan berupa pantun berbahasa Jawanya yang bermakna sindiran kepada kekasihnya.

\section{Leksikon yang diadopsi dari bahasa Inggris}

Leksikon bahasa milenial yang diadopsi dari bahasa inggris cukup banyak. Mengingat bahasa Inggris merupakan bahasa internasional sehingga leksem bahasa Inggris juga diserap sebagai bahasa gaul dan lumrah digunakan dalam komunikasi remaja milenial di media sosial. Berikut tabel leksikon yang diadopsi dari bahasa Inggris. 
Tabel 5 Leksikon yang diadopsi dari bahasa Inggris

\begin{tabular}{|c|c|c|c|}
\hline No & Leksem & Asal Kata/Leksem & Makna \\
\hline $\mathbf{1}$ & $B T W$ & by the way & Ngomong-ngomong \\
\hline 2 & $C O D$ & cash on delivery & Bayar di tempat \\
\hline 3 & OTW & on the way & Sedang di jalan \\
\hline 4 & $D P$ & down paym & Uang muka \\
\hline 5 & $D M$ & direct message & $\begin{array}{l}\text { Pesan yang dikirim langsung } \\
\text { melalui aplikasi Instagram }\end{array}$ \\
\hline 6 & kepo & every particular object. & $\begin{array}{l}\text { Orang yang selalu ingin tahu; } \\
\text { Digunakan untk menyebut } \\
\text { orang yang penasaran dan ingin } \\
\text { tahu segala hal }\end{array}$ \\
\hline 7 & $B F$ & Boy Friend & pacar laki-laki. \\
\hline 8 & Absurd & Absurd & Konyol, aneh, tidak logis \\
\hline 9 & Mainstream & Mainstream & $\begin{array}{l}\text { Sesuatu hal yang sudah sangat } \\
\text { umum. }\end{array}$ \\
\hline 10 & $G W S$ & Get Well Soon & semoga lekas sembuh. \\
\hline 11 & $O M G$ & Oh My God & Ya Tuhan \\
\hline 12 & $F Y P$ & For Your Page & $\begin{array}{l}\text { kata ini ditemukan di aplikasi } \\
\text { tiktok yang artinya muncul di } \\
\text { beranda. }\end{array}$ \\
\hline 13 & $\mathrm{CO}$ & Cekout & $\begin{array}{l}\text { istilah ini sering digunakan oleh } \\
\text { pengguna belanja Online untuk } \\
\text { memastikan barang yang }\end{array}$ \\
\hline
\end{tabular}




\begin{tabular}{l|l|l|l}
\hline & & & $\begin{array}{l}\text { disimpan benar-benar akan } \\
\text { dibeli }\end{array}$ \\
\hline $\mathbf{1 4}$ & LOL & Laugh Out Loud & $\begin{array}{l}\text { atau berarti tertawa terbahak- } \\
\text { bahak. }\end{array}$ \\
\hline $\mathbf{1 5}$ & Cimiw & correct me if in wrong & koreksi bila saya salah \\
\hline $\mathbf{1 6}$ & bro & daro brother & Panggilan untuk teman akrab; \\
\hline
\end{tabular}

Tabel 5 menunjukan beberapa leksikon bahasa remaja milenia yang diadopsi dari bahasa Inggris berjumlah 16 leksem. Berdasarkan bentuknya yaitu $B T W, C O D, O T W, D P$ , DM , kepo, BF , absurd, mainstream, GWS, COD, OMG, FYP, CO,LOL, bro. Berikut konteks beberapa bentuk bahasa milenial di media sosial yang diadopsi dari Bahasa Inggris.

6. @suciani_estuputri: @claurakiehl Pake baju apa juga cocok teruss , 目目

@ airinepenjaga: OMG Beautiful girl (@ claurakiehl/12 Januari 2021)

7. @ovie_aditya : Netizen zheyeenkk btw ini lagu siapa siihh 0

@beetya_beth : Lagu yang viral banget di TikTok (2) At My Worst (@ chikajessica88/13 Januari 2021)

Kalimat 6 ditulis oleh pemilik Instagram @ airinepenjaga di kolom komentar Instagram artis Cinta Laura @ claurakiehl. Dia menggunakan singkatan $O M G$ yang bermakna Ya Tuhan sebagai ungkapan untuk memuji kecantikan Cinta Laura pada foto yang diunggahnya. Kalimat 7 ditulis oleh pemilik akun Instagram @ ovie_aditya di kolom komentar Instagram artis Chika Jesika@chikajessica88. @ Ovie_aditya menggunakan singkatan BTW yang bermakna ngomong-gomong dalam kalimatnya untuk menanyakan lagu tiktok yang mengiringi Chika menari pada video yang diunggahnya.

\section{Leksikon yang Diadopsi dari Bahasa Korea}

Maraknya fenomena pecinta Korea juga mempengaruhi bahasa remaja milenial di Indonesia. Pecinta Korea selalu menggunakan beberapa leksem yang diadopsi dari bahasa Korea dalam percakapan di komunitas pecinta Korea di media sosial. Berikut tabel bahasa milenial yang diadopsi dari bahasa Korea. 
Tabel 6 Leksikon yang diadopsi dari Bahasa Korea

\begin{tabular}{|c|c|c|}
\hline No & Leksem & Makna \\
\hline 1 & dae-bak & $\begin{array}{l}\text { Daebak digunakan untuk menggambarkan } \\
\text { kegembiraan atau ketika mengeluarkan ekspresi kaget } \\
\text { mengenai suatu kejadian luar biasa yang terjadi. }\end{array}$ \\
\hline 2 & Kol & $\begin{array}{l}\text { Kol, merupakan ungkapan yang diberikan sebagai } \\
\text { tanda kalau kamu setuju terhadap sesuatu hal. Misal, } \\
\text { ketika kamu diajak pergi untuk nongkrong di kafe, jika } \\
\text { kamu mengiyakan maka cukup dengan mengatakan } \\
\text { "kol!" yang berarti "aku ikut!". }\end{array}$ \\
\hline 3 & Hwaiting & $\begin{array}{l}\text { Hwaiting diserap dari bahasa Inggris "fighting" dan } \\
\text { digunakan sebagai ungkapan untuk memberi semangat } \\
\text { bagi orang lain maupun untuk diri sendiri. }\end{array}$ \\
\hline 4 & Aigo & $\begin{array}{l}\text { Selain daebak, kalian juga pasti sudah sangat familiar } \\
\text { dengan kata ini. "Aigo" digunakan untuk } \\
\text { mengekspresikan rasa sedih, kecewa, kelelahan dan } \\
\text { perasaan kaget. }\end{array}$ \\
\hline 5 & Aegyo & $\begin{array}{l}\text { aegyo diucapkan untuk menggambarkan tingkah atau } \\
\text { kepribadian yang lucu dan manja seperti anak kecil. } \\
\text { Kata-kata ini lebih sering diucapkan oleh pria kepada } \\
\text { wanita jika mereka sudah merasa gemas dengan } \\
\text { kelakuan sang wanita. }\end{array}$ \\
\hline 6 & 99Line & kelahiran tahun 99 (komunitas Korea) \\
\hline 7 & Mianhae & Berarti maaf \\
\hline 8 & Hyung & $\begin{array}{l}\text { Hyung: panggilan kepada kakak laki-laki dalam } \\
\text { bahasa Korea }\end{array}$ \\
\hline 9 & Ship & $\begin{array}{l}\text { kapal (bahasa Inggris), namun diartikan sebagai } \\
\text { dukung/mendukung oleh Komunitas Korea }\end{array}$ \\
\hline 10 & Kiyowo & Ungkapan pujian yang berarti imut \\
\hline
\end{tabular}




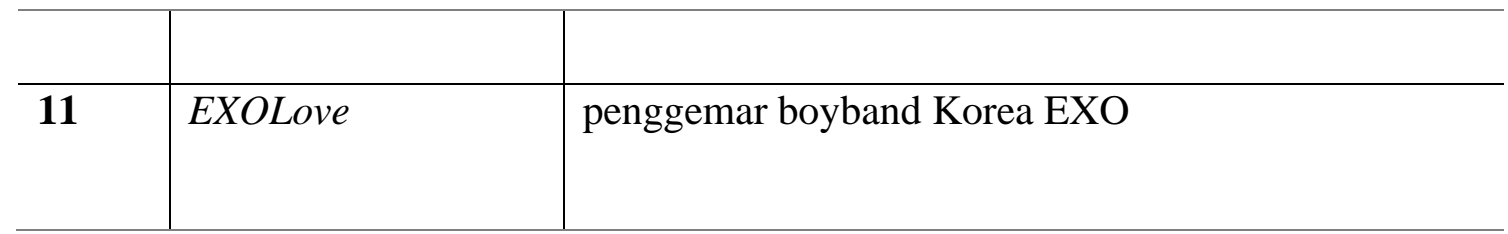

Tabel 6, leksem yang diadopsi dari bahasa Korea umunya digunakan oleh komunitas pecinta Korea di Indonesia . Leksem tersebut berjumlah 11 leksem yang terdiri dari leksem daebak, kol, hwaiting, aigo, aegyo, 99L, mianhae, hyung, ship, kiyomo, EXOL. Berikut Konteks penggunaan leksem tersebut pada komunitas korea di laman tiktok.

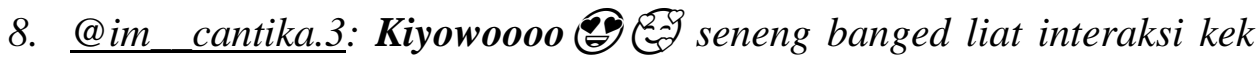
gini :') kangen juga@

@tyra_bubu: Jichu bahagia karna temennya menang beb. Kan sama" 95line eu...masih menunggu interaksi antara anak" 95line @. (@ kpop.indonesian/23 januari 2020)

9. @HAN : Woah, daebak gue yakin sih bapaknya Jaehyun ganteng kayak Jaehyun mana seumuran sama bapak gua lagi.

@AKAHFI: gantengan juga bapak gue (Tiktok/ 25 januari 2020)

Kalimat 8 ditulis oleh @im_cantika.3 pada kolom komentar indtagram @kpop.indonesian . @im_cantika.3 menggunakan kata sapaan Kiyomoo yang memuji wajah Jichu yang bahagia karena melihat temannya sesama anggota 95line menang. Kalimat 9 yang ditulis oleh @HAN pada akun tiktoknya. @HAN menggunakan leksem daebak dalam kalimatnya untuk menggambarkan ekspresi gembira dan kaget karena menganggap hal tersebut luar biasa.

\section{F. SIMPULAN}

Kesimpulan yang dapat dipaparkan dalam penelitian ini adalah leksikon bahasa remaja milenial di sosial media sangat beragam, baik dari pengambilan bahasa daerah ataupun bahasa asing. Penggunaan bahasa remaja milenial pada saat ini sering digunakan secara langsung dalam penggunaan sosial media. Penggunaan bahasa dapat dilihat dari dimensi sosial dan budaya, seperti upacara ritual, peristiwa budaya dan lainnya

Leksikon bahasa remaja milenial di sosial media berdasarkan asal bahasa terdiri dari bahasa Indonesia berjumlah 33 leksem, diadopsi dari bahasa daerah berjumlah 8 leksem, diadopsi dari bahasa Inggris berjumlah 16 leksem, dan diadopsi dari bahasa Korea berjumlah 11 leksem. Adapun bentuk bahasa remaja milenial di media sosial terdiri dari 
beberapa bentuk diantaranya, bentuk singkatan berjumlah 21, bentuk akronim 20, dan bentuk pemendekan kata berjumlah 4. Pembentukan tersebut sebagai upaya untuk mempermudah penulisan serta mengingat maknanya.

\section{G. SARAN}

Bahasa remaja milenial akan terus berkembang seiring dengan kemajuan zaman. Sehingga penelitian ini diharapkan dapat dijadikan sebagai salah satu bahan referensi penelitian selanjutnya yang berhubungan dengan bahasa remaja milenial. Leksikon bahasa remaja milenial dapat dikaji dari beberapa sisi misalkan proses pembentukan kata, cermin budaya, serta pengelompokan bahasa berdasarkan penggunanya. Karena saat proses pengumpulan data peneliti juga mengidentifikasi babarapa bahasa yang khas digunakan oleh komunitas tertentu, misalkan leksikon yang diadobsi dari bahasa Korea biasa digunakan oleh komunitas pecinta Korea. Begitu juga komunitas remaja pada suatu daerah juga memiliki bahasa gaul yang diadobsi dari bahasa daerahnya.

\section{DAFTAR PUSTAKA}

Abdullah, Wakit. 2013. Etnolinguistik: Teori, Metode dan Aplikasinya. Solo: Universitas Sebelas Maret Surakarta.

Alwasillah, A. Chaedar.1986. Sosiologi Bahasa. Bandung: Angkasa

Alwi, Hasan dkk.2007. Tata Bahasa Baku Bahasa Indonesia. Jakarta : Balai Pustaka

Arisanti, Lida Yosi. 2018. Penggunaan Akronim dan singkatan Dalam Media Sosial Facebook di Kalangan Remaja SMK Plus Multazam. Literasi Vol 2 No 2. Hlm. $104-112$

Chaer Abdul. 2003. Seputar Tata Bahasa Baku .Jakarta: Rineka Cipta

Chaer, Abdul. 2009. Psikolinguistik. Kajian Teoretik. Jakarta: Rineka Cipta.

Departemen Pendidikan Nasional. 2012. Kamus Besar Bahasa Indonesia Pusat Bahasa. Jakarta : PT Gramedia Pustaka Utama.

Durati, Alessandro.1997. Linguistic Anthrophology. New York. Cambridge Univerity Press. Ertika, Reza dkk. 2019. "Ragam Bahasa Gaul Kalangan Remaja di Kota Bengkulu”.Jurnal Ilmiah KORPUS Vol 2 No 1. Hlm. 84 - 91

Goziyah dan Maulana. 2019. "Bahasa Gaul Generasi Milenial di sosial Media”. Semiba. Hlm $120-125$

Hamdi, Asep Saipul, dan E Bahruddin. 2014. Metode Penelitian Kuantitatif Aplikasi dalam Pendidikan. Sleman:DEEPUBLISH. 18 Juni 2020

Hilman, Aryanah, Burhanuddin, Saharudin. 2020. Wujud Kebudayaan Dalam Tradisi Suna Ro Ndoso: Kajian Etnolinguistik. Jurnal Basastra Vol 9 no 3. Hlm 256-270

Husain, Abdul Rajak. 1994. Kamus Resmi Singktan dan Akronim Baku Bahasa Indonesia. Semarang: Solo Aneka

Kridalaksana, H. 2001. Kamus Linguistik. Jakarta: Gramedia. 
Kridalaksana, H. 2007. Pembentukan kata dalam Bahasa Indonesia. Jakarta: Gramedia Pustaka Utama

Mamik. 2015. Metodologi Kualitatif Google Book. Sidoarjo: Zifatama Publiser. 29 januari 2021

Mbete, A.M. 2007. “Ekologi Bahasa”. Bahan Matrikulasi Program Magister Linguistik PPS Universitas Udayana 2007.

Putro, Khamim zarkasi. 2017. Memahami Ciri Dan Tugas Perkembangan Masa Remaja. Jurnal Aplikasia Vol 17 No 1. Hlm 25 - 32

Sudaryanto. 1993. Metode dan Aneka Teknik Analisis Bahasa. Yogyakarta: Duta Wacana University Press

Sutardi, Tedi. 2007. Antropologi: Mengungkap Keragaman Budaya. Bandung: PT Setia Purna Inves

Swandy N, Eduardus. 2017. "Bahasa Gaul Remaja Dalam Media Sosial Facebook". Jurnal BatraVol 1 No 4 . Hlm. 1-19

Wijana, I Dewa Putu. 2010. Bahasa Gaul Remaja Indonesia. Yogyakarta: Aditya Media Publishing 